\title{
A DEUSA COMPÕE UM "MITO": O JOVEM ODISSEU EM BUSCA DE VENENO (ODISSEIA I, 255-68)
}

\author{
Christian Werner* \\ Universidade de São Paulo
}

\begin{abstract}
This paper explores the inter- and extradiegetical functions of a story about Odysseus narrated by Athena to Telemachos in Odyssey 1, 255-68. It is argued that the representation of Odysseus in search of poison for his arrows need not to be thought first and foremost as a non-Homeric element or a morally disturbing action, for it may be analyzed by means of epic themes (specially by the mêtis-megatheme) explored not only in the Odyssey but in the Iliad as well. Besides, this story anticipates and condenses the plot of the poem.
\end{abstract}

KEYWORDS: Odyssey; Iliad; theme; myth; archer.

e través de um longo discurso no início da Odisseia (Od. I, 253-305), ${ }^{1}$ Atena, disfarçada do táfio Mentes, finalmente consegue fazer Telêmaco deixar de lado sua inércia e ceticismo, gerados pela ausência do pai, e passar a agir - de forma intermitente e nem sempre muito decidida, é verdade - como dono de sua propriedade e legítimo representante de sua gloriosa linhagem. ${ }^{2}$ Fundamental como elemento persuasivo e

\footnotetext{
*crwerner@usp.br

${ }^{1}$ Os textos gregos da Ilíada e da Odisseia (doravante abreviados por Il. e Od.) citados são os seguintes: Homeri Odyssea. Recognovit Helmut van Thiel. Hildesheim: Olms, 1991, e Homeri "Ilias". Iterum recognovit Helmut van Thiel. Hildesheim: Olms, 2010. Todas as traduções, dessas e de outras obras em língua estrangeira, são minhas. Os trechos traduzidos da Odisseia fazem parte da minha tradução completa do poema, ainda inédita.
} 
motivador é a história através da qual Atena/ Mentes conta como Odisseu, em um passado distante, conseguiu obter veneno para suas flechas - combinação singular nos poemas homéricos - de se pai:

Ah! Se de volta à casa, nas portas da frente, estivesse com elmo, escudo e duas lanças, tal como eu pela primeira vez o mirei, em nossa casa bebendo e deleitando-se, voltando de Éfira, de junto de Ilo, filho de Mermero, pois foi também até lá sobre nau veloz, Odisseu, em busca de poção homicida para com ela untar flechas ponta-brônzea. Mas aquele não lha deu, pois temia indignar os deuses sempre vivos; mas meu pai lha deu, pois o amava por demais. Assim encontrasse os pretendentes Odisseu; todos seriam destino-veloz e bodas-amargas. (Od. I, 255-266) ${ }^{3}$

Vários críticos, de forma mais ou menos escandalizada, rejeitaram essa história como imprópria do herói homérico, vale dizer, épico. A representação de Odisseu conteria resquícios da figura de um "arquitrickster", herança autólica que o(s) autor(es) da Ilíada e da Odisseia

\footnotetext{
${ }^{2}$ Para discutir com mais precisão de que forma Atena, através dessa fala, consegue uma mudança de postura por parte de Telêmaco, seria necessário examinar todo o diálogo entre a deusa e o jovem, o que fiz em outro texto, apresentado numa primeira versão como conferência e a ser publicado sob o título "A presença do ausente: a performance do kleos no canto I da Odisseia".

${ }^{3}$ Não entrarei na questão sobre a "veracidade" ou não da história: para alguns, tratase obviamente de uma mentira (cf. Louden, B. The "Odyssey". Structure, narration and meaning. Baltimore: Johns Hopkins University Press, 1999, p. 26) ou "lembrança fictícia" (cf. Danek, G. Epos und Zitat. Studien zu den Quellen der Odyssee. Wien: Österreichischen Akademie der Wissenschaften, 1998. p. 56-57), ao passo que, para outros, não há nenhuma razão para considerá-la uma invenção (cf. de Jong, I. J. F. A narratological Commentary on the "Odyssey". Cambridge: University Press, 2001, p. 32). Mais cuidadosa é West, S. Books i-iv. In: Hainsworth, J. B.; Heubeck, A.; . (Org.). A Commentary on Homer's "Odyssey". Oxford: University Press, 1988. v. I, p. 107; a autora apresenta a mesma oposição, mas não toma partido. Rüter, K. Odysseeinterpretationen. Untersuchungen zum ersten Buch und zur Phaiakis. Editado por K. Matthiessen. Göttingen: Vandenhoeck \& Ruprecht, 1969, p. 155-56, separa as duas escalas do roteiro de Odisseu em duas "histórias": a de Éfira, a transmitida pela tradição, e a de Anquíalo, a nova, inventada (de forma semelhante, Danek, op. cit., p. 112). O estrato antigo, conhecido pelo público, legitimaria o novo.
} 
teria(m) sido maximamente zeloso(s) em purgar, ou então que o autor da Odisseia usaria para criar um chiaroscuro que destacaria o problema moral da vingança de Odisseu ou a oposição entre dois modos de pensamento ou ação, só um deles épico-heroico. ${ }^{4}$ Embora alguns críticos reconheçam que a história prefigure, de forma mais ou menos enfática, a vingança contra os pretendentes (função extradiegética) ${ }^{5}$ e, além disso, contenha um modelo de ação para Telêmaco, mais particularmente, a sugestão de que só através de um ardil poder-se-ia vencer um bando tão numeroso (função intradiegética), ${ }^{6}$ mesmo esses críticos comumente colocam um suposto problema moral no centro da história. ${ }^{7}$ Assim, o que farei aqui é colocar em questão a moralização dessa história através (1) da discussão do tipo de discurso que ela implica e (2) e (3) da análise dos temas épicos que ela pressupõe.

\footnotetext{
${ }^{4}$ Cf., por exemplo, Merkelbach, R. Untersuchungen zur Odyssee. 2. ed. München: Beck, 1969, p. 122-123, e Dirlmeier, F. Die Giftpfeile des Odysseus. Heidelberg: Carl Winter, 1966 (com quem concorda Hölscher, U. Die Odyssee. Epos zwischen Märchen und Roman. München: C. H. Beck, 1988, p. 71-73). Clay, J. S. Odyssean animadversions. In: Montanari, F. (Org.). Omero tremila anni dopo. Roma: Edizioni di Storia e Letteratura, retoma sua interpretação de The wrath of Athena. Gods and men in the "Odyssey". Lanham: Rowman \& Littlefield, 1997, p. 71-72, defendendo que o poeta da Odisseia quis manter a duplicidade de Odisseu: a Odisseia apresenta dois Odisseus numa tensão incompletamente resolvida. A versão sombria de Odisseu não é apagada; a menção de Atena/ Mentes a "meu pai" nos faria perguntar que Zeus é esse. Nada nos garante que o poeta não queira manter as duas imagens de Odisseu na nossa frente. Danek, op. cit., p. 56, propõe que a história revela uma oposição entre duas táticas: a "ação não-heroica e desleal", provavelmente presente em outras versões da vingança contra os pretendentes, e o "combate heroico". Por fim, West, op. cit., p. 107, menciona a piedade de Odisseu (reiterada ao longo do poema) como em oposição ao relatado na história.

${ }^{5}$ Cf. Louden, op. cit., p. 16; de Jong, op. cit., p. 32-33; e Danek, op. cit., p. 56-57.

${ }^{6}$ Cf. van Thiel, H. Odysseen. Basel: Schwabe, 1988, p. 42.

${ }^{7}$ Cf., por exemplo, formulação de Dimock, G.E. The unity of the "Odyssey". Amherst: University of Massachusetts Press, 1989, p. 18.

${ }^{8}$ Uso "tema" (e o adjetivo derivado) da forma como o define e discute Lord, A. B. The singer of tales. Cambridge, Mass.: Harvard University Press, 1960; o conceito foi aperfeiçoado por John M. Foley em vários livros e artigos, e é utilizado na análise de um livro importante para este artigo: Dué, C.; Abbott, M. "Iliad" 10 and the poetics of ambush. A multitext edition with essays and Commentary. Hellenic Studies 39. Washington D.C.: Center for Hellenic Studies, 2010.
} 
Antes de discutir qual o sentido dessa breve história, é necessário contextualizá-la brevemente no discurso em que se encontra embutida, ou melhor, na polêmica em torno desse discurso que, durante muito tempo, esteve no centro da discussão filológica envolvendo a Odisseia. ${ }^{9}$

Se considerarmos que a filologia alemã moderna iniciou com a publicação de um livro sobre Homero (Prolegomena ad Homerum, publicado por Friedrich A. Wolf em 1795), poucas décadas se passaram antes que a Odisseia começasse a ser dissecada de uma forma que se tornou bastante profícua durante pelo menos um século. Em especial a partir de Adolf Kirchhoff e seu livro de 1859 (Die Homerische Odyssee), problematizou-se a relação entre o canto I e um suposto poema independente que antecederia nossa Odisseia e que passou a ser nomeado pela crítica (chamada "analítica" ou simplesmente Análise) como a "Telemaquia", cujo núcleo seriam os cantos (I e) II a IV (e a primeira parte do canto XV). ${ }^{10} \mathrm{O}$ problema central da Odisseia passou a ser a relação entre a viagem de Telêmaco e o retorno de Odisseu.

Para parte da crítica que seguiu essa linha de interpretação, o responsável pela versão unificada da Odisseia teria, de forma canhestra, composto o canto I como uma introdução à união entre, de um lado, as aventuras de Telêmaco e, de outro, o retorno e a vingança de Odisseu. $\mathrm{O}$ fato de tal discussão ter sido deslocada pelos pressupostos da teoria oral de Milman Parry, Albert B. Lord e seus seguidores, de um lado, e pelas tentativas de interpretação dos poemas como unidades literárias (os "unitários") não elimina, por completo, a relevância dos vários problemas assinalados por quatro ou cinco gerações da Análise. Basta ter em vista, por exemplo, que mesmo o grande homerista (unitário no que diz respeito à Ilíada) Wolfgand Schadewaldt ainda acreditava, para a Odisseia, num poema independente narrando as aventuras de Telêmaco. ${ }^{11}$

\section{Ainos, mythos e o discurso de Atena}

Embora não nos seja indicado que tipo de discurso é a história contada por Atena, podemos defini-lo a partir das várias expressões usadas na

\footnotetext{
${ }^{9}$ Cf., por ex., Rüter, op. cit.

${ }^{10} \mathrm{O}$ primeiro a propor a existência de um poema independente sobre Telêmaco que poderíamos identificar na nossa Odisseia foi Johann G. J. Hermann em De interpolationibus Homeri dissertatio (1832); cf. Rüter, op. cit., p. 18.

${ }^{11}$ Para um resumo da história das interpretações, cf. Rüter, op. cit., p. 13-25.
} 
poesia homérica referentes a práticas discursivas e poéticas que, direta ou indiretamente, são associadas à própria narrativa ou aos seus limites em relação a outros tipos de discurso. Algumas delas são aoidê ("canto"), kléos ("glória, fama"), kléa andrôn ("ações gloriosas dos homens"), phéme ("prenúncio"), phêmis ("dito, boato"), mûthos ("discurso, história"), épos ("fala"), aînos ("história") e óssa ("boato, notícia"), ${ }^{12}$ expressões cuja tradução não dá conta, vale notar, da especificidade semântica do original.

Na poesia homérica, o aînos (Il. XXXIII, 652 e 795; Od. XIV, 508; XXI, 110) refere-se a um modo de discurso que envolve um elogio. ${ }^{13}$ Ao mesmo tempo, como é o caso em duas passagens (Il. XXIII, 652; Od. XIV, 508), ${ }^{14}$ pode conter uma mensagem que não é explicita, mas está embutida em uma história, e, portanto, deve ser decifrada pelo interlocutor, podendo ou não ser explicitada pelo falante. Do ponto de vista da dicção homérica, trata-se, na verdade, de um tipo de mûthos, o qual foi assim definido por Richard Martin: "Mûthos é, em Homero, um ato de fala que indica autoridade, cuja performance é detalhada, geralmente em público, com um foco na atenção total a cada detalhe". ${ }^{15}$

${ }^{12}$ Cf. Martin, R. P. The language of heroes. Speech and performance in the "Iliad". Ithaca: Cornell University Press, 1989; Ford, A. Homer: the poetry of the past. Ithaca: Cornell University Press, 1992; Bakker, E. Polyphemos. Colby Quarterly. Waterville, n. XXXVIII, p. 135-50, 2002. Cf. também, de minha autoria, o artigo mencionado supra, n. 2, e o artigo "Reputação e presságio na assembleia homérica: polúphemos em Odisseia 2, 150", submetido a publicação em 2010.

${ }^{13}$ Acerca da poética do aînos (na poesia hexamétrica, elegíaca e mélica), cf. Nagy, G. The best of the Achaeans. Concepts of the hero in archaic Greek poetry. Baltimore: Johns Hopkins University Press, 1979, p. 222-241.

${ }^{14}$ Em Od. XXI, 110, embora o sentido de aînos possa ser o de "elogio" [cf. H.-J. Mette em Snell, B. (Begründer). Lexikon des frühgriechischen Epos. Göttingen: Vandenhoeck \& Ruprecht, 1979. Vol. I, col. 324], é o próprio Telêmaco que usa o termo ao se referir ao que acabara de dizer sobre Penélope, e ele o faz em um discurso extremamente elusivo; cf. Halliwell, S. Greek laughter. A study of cultural psychology from Homer to earlychristianity. Cambridge: University Press, 2008, p. 96-97.

${ }^{15}$ Cf. Martin, op. cit., p. 12. Em referência à Il. XXIII, 624-52, o narrador introduz a fala de Nestor como "palavras aladas (ou plumadas)" (épea pteróenta, v. 625), a recorrente expressão homérica que, segundo Martin, op. cit., p. 27-37, é sinônima de mûthos. Após a fala de Nestor, porém, o narrador denomina seu discurso aînos, mas ele o faz através da percepção de Aquiles por meio de um "imperfeito focalizante": "Assim falou; e o filho de Peleu atravessou a espessa multidão de aqueus após ouvir toda a história (aînon epéklue) do filho de Neleu” (v. 651-652). Acerca do "focalizing' imperfect”, cf. Rijksbaron, A. Discourse cohesion in the proem of Hesiod's "Theogony". In: 
Tais características de um aînos também se revelam na polissemia de um epíteto de Odisseu, polúainos, que os léxicos costumam glosar por "muito elogiado, de grande fama" e "com muitas palavras, que conhece muitas histórias". ${ }^{16}$ É justamente para explorar esse duplo caráter do termo, que diz respeito a um discurso que, ao mesmo tempo, contém elogios e/ ou histórias com um caráter encomiástico, discurso esse que depende, para se efetivar por completo, da correta interpretação por parte dos ouvintes, ${ }^{17}$ que será examinada a história narrada de forma sucinta a Telêmaco por Atena.

Após a assembleia de deuses que inicia a ação propriamente dita do poema (Od. I, 26-95), Atena vai a Ítaca disfarçada do táfio Mentes, um antigo xénios, ou seja, um aliado por laços de hospitalidade, de Odisseu (v. 96-181). Nessa cena-típica de visita, ${ }^{18}$ pondo em prática o que foi deliberado no Olimpo, a deusa convence Telêmaco, o filho do herói, a proceder a uma viagem em busca de notícias do pai, o que irá perfazer os eventos narrados nos cantos I a IV e o início do canto XV. ${ }^{19}$

Para convencer Telêmaco a empreender tal viagem, Atena/ Mentes precisa desenvolver um longo exercício de persuasão (Od. 1, 182-324), já que o jovem está longe de acreditar que o pai esteja vivo e retornará a Ítaca, e tudo o que parece acerca dele ter ouvido está em notório contraste com o que ele mesmo sofre no presente, ao ver sua propriedade ser dilapidada pelos mais de cem jovens pretendentes de sua mãe. Nesse momento da história, portanto, a postura de Telêmaco é marcada pela

Bakker, S.; Wakker, G. (Org.). Discourse cohesion in ancient Greek. Leiden/ Boston: Brill, 2009, p. 245-47. Assim, essa passagem sugere que o ainos, assim como a prece, o lamento, a súplica, o comando, o insulto e a narração de memória é um gênero verbal com fundamento social (cf. Martin, op. cit., p. 44). Compare também Il. XXIII, 786 (o narrador chama o discurso de Antíloco de mûthos) e o v. 795 (Aquiles refere-se ao mesmo discurso como um aînos).

${ }^{16}$ Cf. G. Markwald em Snell, B. (Begründer). Lexikon des frühgriechischen Epos. Göttingen: Vandenhoeck \& Ruprecht, 2004. Vol. III, col. 1381.

${ }^{17}$ Cf. Nagy, G. Pindar's Homer. The lyric possession of an epic past. London/ Baltimore: Johns Hopkins University Press, 1990, p. 148.

${ }^{18}$ Sobre tal cena-típica, cf. Reece, S. The strangers welcome. Oral theory and the aesthetics of Homeric hospitality scene. Ann Arbor: University of Michigan Press, 1993, e de Jong, op. cit., p. 17-18.

${ }^{19}$ Para alguns críticos (por ex., Louden, op. cit., p. 25-28 e 101), a visita de Atena prefigura o papel de Odisseu em Ítaca na segunda metade do poema, ambas sendo variações de uma "teoxenia". 
passividade, e é dela que Atena precisa tirá-lo. Para isso, ela não apenas lhe diz o que poderia fazer, mas usa diversas imagens e relatos que evidenciam como ele poderia agir, imagens e relatos que reiteram a autoridade que a deusa exerce naquele momento sobre o mortal e que é consubstanciada no seu discurso. Essa autoridade não só é explicitada quando a própria Atena denomina sua fala "mûthoi" (v. 271), mas também quando Telêmaco a compara a uma figura paterna (v. 308). Além disso, autoridade semelhante àquela que, através de seu discurso, Atena-comopai exerce sobre Telêmaco-como-filho ela quer que o jovem, também por meio de um mûthos (v. 273), demonstre, no dia seguinte, sobre a assembleia de itacenses, ou seja, na ausência de Odisseu - e, consequentemente, de uma figura com poder de rei em Ítaca (v. 400-1) - é Telêmaco que deverá se comportar com a autoridade de um rei-pai diante dos seus concidadãos:

Vamos agora, ouve e atenta a meu discurso: amanhã, após convocar à ágora os heróis aqueus, discurso enuncia a todos, e que deuses o testemunhem.

(...) Mas eu à nau veloz descerei agora, até os companheiros, que, impacientes, me aguardam; que a ti isso ocupe, e atenta a meu discurso. (Od. I, 271-73+303-5)

\section{0 arqueiro}

Voltando à história da busca do veneno, comecemos pelo que ela traz de aparentemente estranho. Em primeiro lugar, tem-se a combinação, na imagem de Odisseu construída pela deusa, das armas do guerreiro (proto-)hoplita, de um lado, com o arco, de outro. ${ }^{20}$ Essa junção, embora não seja completamente inusitada em Homero, ${ }^{21}$ chama a atenção pela importância (qualitativa mais que quantitativa: não são muitos os momentos em que Odisseu aparece como arqueiro por

\footnotetext{
${ }^{20}$ Acerca dos modos de o herói homérico combater e da sua possível relação com a realidade histórica, cf., por ex., van Wees, H. Homeric warfare. In: Morris, I.; Powell, B. (orgs.) A new Companion to Homer. Leiden: Brill, 1997. Outro herói que combina os dois modos de armar-se é Páris (Il. III, 15-18).

${ }^{21}$ Cf. Papadopoulou, T. Heracles and Euripidean tragedy. Cambridge: University Press, 2005, p. 142, e Stoevesandt, M. Homer "Ilias": Gesamtkommentar. Band IV: Sechster Gesang. Faszikel 2: Kommentar. Berlin: Walter de Gruyter, 2008, p. 19-20.
} 
excelência, mas eles são bastante significativos) dada na Odisseia à habilidade de Odisseu com o arco em contraposição à caracterização do herói na Ilíada, onde nenhuma menção direta dessa habilidade ocorre. ${ }^{22}$ Podemos nos perguntar, portanto, por que, se levarmos em conta ambos os poemas, Odisseu deixou seu arco em casa, sendo ele tão potente arqueiro e seu arco, tão especial.

A anedota de Odisseu não ocupou a Análise de modo tão obsessivo quanto o restante do discurso de Atena. ${ }^{23} \mathrm{Um}$ crítico que a examinou com certa simpatia foi Reinhold Merkelbach, autor de um dos modelos mais complexos do poema. Grosso modo, ele propôs um "poema da vingança" (R, de "Rachegedicht", composto pelo Homero legítimo, bem entendido), no qual Odisseu utilizaria apenas o arco para se livrar dos pretendentes. ${ }^{24}$ Esse poema seria mais antigo (que o poema A, no qual as armas hoplíticas teriam sido introduzidas na vingança), refletindo uma época histórica na qual até mesmo flechas envenenadas não representariam uma falha moral.

Uma resposta a essa leitura em camadas foi dada por Franz Dirlmeier, para quem o uso do arco e, em especial, a menção de flechas envenenadas, remeteria a um Odisseu pré-homérico, quiçá pré-grego, que estaria presente na nossa Odisseia graças ao modus operandi do poeta (com formação) oral, que simplesmente incorporaria material tradicional, sem se preocupar demasiadamente até que ponto esse material se adequaria

${ }^{22}$ A exceção é Il.X, 260: no meio da noite, os chefes aqueus decidem enviar uma missão até o acampamento troiano e Odisseu, desarmado e longe da sua cabana, recebe as armas de Meríones; entre elas, um arco. Mesmo se levarmos em conta que Meríones é, mais de uma vez, apresentado como arqueiro (cf. Hainsworth, J. B. The "Iliad": a Commentary. Vol. 3: Books 9-12. Cambridge: University Press, 1993, p. 179), isso não elimina necessariamente a evocação de um provável tema tradicional, qual seja, a excelência ímpar de Odisseu na astúcia, manifestada por meio de sua habilidade com o arco e, homologamente, na condução de uma tocaia (cf. Danek, G. Studien zur Dolonie. Wien: Österreichischen Akademie der Wissenschaften, 1988, p. 218, n. 92, e Dué e Ebbott, op. cit., p. 57). Quanto à Odisseia, por um lado, Odisseu menciona que ninguém, salvo Filoctetes, o superava no domínio do arco em Troia (Od. VIII, 219-21); por outro lado, é-nos informado que seu notável arco foi deixado em Ítaca (Od.XXI, 38-41). Dessa forma, indiretamente, a Odisseia, talvez mais que justificar por que tão valiosa arma não foi perdida com tudo o que Odisseu trouxe de Troia, assinala a sua singularidade em relação ao outro poema.

${ }^{23}$ Isso ocorreu em razão de parte da crítica considerar a maior parte do canto I derivativo, ou seja, composto por um mau poeta a partir dos cantos II-IV.

${ }^{24}$ Cf. Merkelbach, op. cit., 122-123. 
ao modo como constrói sua história e caracteriza sua personagem: a anedota comporia uma parte da biografia não-troiana, iliádicoaristocrática de Odisseu. ${ }^{25}$ Uma solução como essa, porém, exemplifica a conclusão de Jean Bollack ao equiparar a Análise e (eu acrescentaria: certas facções d)a Teoria Oral: ${ }^{26}$ seja por meio de uma mera identificação daquilo que permanece no texto por ser tradicional (Teoria Oral) seja pela operação de um mau poeta ou um editor incompetente (Análise), o intérprete não forneceria, de fato, uma interpretação do texto.

Um dos argumentos de Dirlmeier baseia-se no suposto estatuto negativo do arco em Homero, em especial, na Ilíada. ${ }^{27}$ Todavia, a tentativa de isolar o arco das armas ou táticas supostamente "nobres" usadas pelos heróis homéricos, em especial, iliádicos, não é convincente. ${ }^{28}$ Ainda que deixássemos de lado ser o arco a arma de $A_{p o l o}{ }^{29}$ e do grande ainda que ambíguo - herói que é Héracles, ${ }^{30}$ há várias passagens na

${ }^{25}$ Cf. Dirlmeier, op. cit., p. $19-22$.

${ }^{26}$ Cf. Bollack, J. Ulysse chez les philologues. In: La Grèce de personne. Paris: Seuil, 1997, p. 56-59.

${ }^{27}$ Cf. Dirlmeier, op. cit., p. 8-12.

${ }^{28}$ Assim como o arco, a tocaia (lókhos) - ou seja, o ataque de surpresa, quando se usa algum tipo de esconderijo, o sangue frio é fundamental e se faz necessário determinar-se o momento correto de agir (kairós) - é uma tática relativamente pouco mencionada na Ilíada, mas de modo algum menosprezada ou rebaixada. Para Edwards, A. T. Achilles in the "Odyssey”. Königstein: Hain, 1985, p. 26, "a Ilíada tende a ver o lókhos como uma estratégia empregada pelos fracos e covardes e a opô-la ao herói singular, invencível". O texto de Edwards contém algumas generalizações que me parecem indevidas, como a de que a tocaia "é de importância estratégica inferior à batalha feita de pé". Haft, A. J. "The city-sacker Odysseus" in "Iliad" 2 and 10. Transactions of the American Philological Association. Baltimore, n. CXX, 1990, p. 56, n. 55, assinala que as conclusões de Edwards acerca da tocaia na Ilíada são prejudicadas por ele conferir ênfase excessiva às tocaias mais negativas do poema. Para uma nova interpretação do valor da tocaia - e, consequentemente, da arma tematicamente a ela associada, o arco -, cf. Dué e Ebbott, op. cit., passim (acerca do arco, especialmente p. 57-62), em especial, a crítica à utilização de expressões como "não homérico" ou "não heroico" no tratamento do tema e de seus subtemas.

${ }^{29}$ Il. I, 45 e especialmente o Hino Homérico a Apolo 1-9 (em Richardson, N. Three Homeric hymns: to Apollo, Hermes, and Aphrodite. Cambridge: University Press, 2010, p. 37 e 81-83).

${ }^{30}$ Mas ambivalente também é Aquiles! Acerca da ambivalência de Héracles, cf. Papadopoulou, op. cit., p. 5. Na Ilíada, não se menciona o arco de Héracles, herói que pertence à geração anterior àquela dos que lutam em Troia (Il. V, 635-39). 
Ilíada que atestam que o uso do arco não é intrinsecamente desonroso, ${ }^{31}$ nem "arcaizante" nem "étnico". ${ }^{32}$ Por certo os heróis mais varonis do poema, como Aquiles, Diomedes, Odisseu e Pátroclo, do lado grego, e Heitor, Eneias e Sarpédon, do lado troiano, não o usam, o que, todavia, não desqualifica, a priori, a arma. Isso não significa desconsiderar que os próprios heróis (de forma mais saliente que o narrador) louvem o combate mano a mano em detrimento do combate à distância (um exemplo é a fala de Diomedes no canto XI, mencionada abaixo). Boa parte dos intérpretes da Ilíada, porém, defende que o poema confere máximo valor às conquistas obtidas pela força e mínima àquelas resultantes da astúcia, com o que simplificam o texto. ${ }^{33}$

Quanto ao lado troiano, para sublinhar a excelência de Pândaro, diz-se que o herói ganhou seu arco de Apolo. ${ }^{34}$ No acampamento aqueu, por sua vez, Teucro é um grande arqueiro, e o valor dessa habilidade não é diminuído por usar outras armas. ${ }^{35} \mathrm{Da}$ mesma forma, flechadas do troiano Páris e do grego Filoctetes serão importantes no desfecho

\footnotetext{
${ }^{31}$ Como parece afirmar Mackie, H. Talking Trojan. Speech and community in the "Iliad". Lanham: Rowman \& Littlefield, 1996, p. 50: "As descrições de Páris e Pândaros nesses cantos (sc. V e XI) sugerem que combater com arco e flecha, da mesma forma que fugir da lança de um inimigo, envolve evitar-se o combate mano a mano". Não há nada de intrinsecamente negativo no fato de um arqueiro esconderse quando está atirando, já que a falta de uma armadura o torna particularmente vulnerável; cf. Stoevesandt, op. cit., p. 114.

${ }^{32}$ Cf. Hunt, P. Military forces. In: Sabin, P.; van Wees, H.; Whitby, M. (Org.). The Cambridge history of Greek and Roman warfare. Cambridge: University Press, 2008. Vol. 1, p. 121: "Em Homero, vários heróis usam o arco, mas sua reputação era variada"; idem Stoevesandt, op. cit., p. 114. Mackie, op. cit., p. 51-53, nota que o modo furtivo de combate exemplificado pelo arqueiro é mais comum entre troianos que aqueus.

${ }^{33}$ Cf., por exemplo, a intervenção dos deuses nas mortes de Pátroclo e Heitor, a corrida de carros no canto XXIII e a descrição do contingente de arqueiros de Filoctetes (Il. II, 719-20; acerca dessa passagem, cf. Latacz, J. et al. Homer "Ilias": Gesamtkommentar. Band II: Zweiter Gesang. Faszikel 2: Kommentar. München: Saur, 2003, p. 233), para citar apenas algumas passagens que conferem outras nuances à questão. Cf. também Dué e Ebbott, op. cit., passim, sobretudo p. 31-88: as autoras mostram que o arco e a tocaia fazem parte do "megatema" épico que é a "astúcia".

${ }^{34} \mathrm{Il}$. II, 827; algo semelhante é dito de Teucro em Il. XV, 440.

${ }^{35}$ Ao lutar com Ájax, ele lança suas flechas e, em seguida, se protege atrás do escudo do outro herói (Il. VIII, 266-72); a sincronia entre os dois é destacada em Il. XII, 387-89. Lembremo-nos, por fim, que a disputa com o arco faz parte dos jogos no funeral de Pátroclo, ainda que seja a última prova $(23,850-83)$.
} 
da guerra, o que não é narrado na Ilíada. A propósito, informa-se no Catálogo das Naus que o hábil manejo do arco não é somente uma característica de Filoctetes, mas de todo o seu contingente (Il. II, 718-20).

Que o arco pode dar glória imortal a um herói, isso se depreende do comentário feito por Agamêmnon ao chamar um médico para cuidar de Menelau, ferido pela flecha de Pândaro:

Taltíbio, convoca Macáon o mais rápido possível para cá, o filho varonil de Asclépio, médico impecável, para que veja o guerreiro Menelau, filho de Atreu, pois com uma flecha o atingiu um bom conhecedor do arco, troiano ou lício, e para esse há glória (kléos), e para nós, aflição.

(Il. IV, 193-97)

Por outro lado, a passagem onde mais claramente é feita uma crítica ao uso do arco como arma no campo de batalha é no canto XI, ${ }^{37}$ quando Diomedes é atingido por Páris e censura seu inimigo:
Arqueiro, ofensor, radiante com o corno, namorador, se tentasses o mano a mano com armas, não te protegeriam o arco e as flechas em massa; agora riscaste-me o tarso do pé e te jactas assim.
Ignoro-o, como se me atingisse mulher ou criança insensata; vão é o projétil do varão covarde que não é de nada. Diferente se vem de mim: embora toque por pouco, afiado é o projétil, e de imediato deixa sem vida. (II.XI, 385-92)

Mesmo aqui, porém, não é necessário ler-se uma crítica genérica ao arco, própria de um suposto código aristocrático ou guerreiro. Não me parece que Páris seja criticado apenas, ou mesmo principalmente,

\footnotetext{
${ }^{36}$ Essa passagem é geralmente deixada de lado por aqueles que defendem uma inferioridade absoluta do arco. Para Dirlmeier, op. cit., p. 8, o acordo ser quebrado por meio de um arco aponta para a baixeza da ação; contra Dué e Ebbott, op. cit., p. 59-60. Para uma interpretação da passagem que aponta para a vileza da ação - mas não do meio usado para ela - cf. Rousseau, P. L'intrigue de Zeus. Europe. Paris, n. QXXXLXV, p. 132-37, 2001, que defende a homologia entre essa cena e a quebra dos laços de hospitalidade por parte de Páris quando de sua visita a Menelau em Esparta.

${ }^{37} \mathrm{O}$ termo iomôroi, usado numa censura (Il. IV, 242), tem etimologia e sentido incertos; cf. W. Beck em Snell, B. (Begründer). Lexikon des frühgriechischen Epos. Göttingen: Vandenhoeck \& Ruprecht, 1991. Vol. 2, col. 1198.
} 
pela sua tática; o que Diomedes faz é responder à jactância do outro herói (v. 380-383), de sorte que devemos levar em conta os protocolos do gênero neîkos ("ofensa"). ${ }^{38}$ A crítica de Diomedes talvez seja também incitada pelo fato de Páris, que atirou de uma tocaia (v. 379), blasonar seu feito, quando a jactância parece ser protocolo específico do combate aberto entre dois guerreiros. ${ }^{39}$ Assim, se levarmos em conta, como mostra Anthony T. Edwards, ${ }^{40}$ que a emboscada geralmente não é um ato solo, mas executada por um grupo de elite, talvez possamos afirmar que Páris, inabilmente ou dando mostras do seu tipo de heroicidade, ou bem misture protocolos que normalmente estão separados ou bem os use mal. ${ }^{41}$ Por fim, é curioso que Diomedes deixe o campo de batalha pela última vez no poema fazendo aquilo de que Agamêmnon o acusa no início (Il. IV, 370-400), ou seja, falar demais. Tendo em vista, porém, que acabou de ferir Heitor, seu neîkos certamente não o desmerece. ${ }^{42}$

Se na Ilíada, portanto, o arco não é, em si, uma arma de covardes, na Odisseia ele o é menos ainda. O que diferencia os poemas, porém, é que o herói principal da Odisseia, Odisseu, na sua grande aristeía, faz uso, primeiro, do arco, e depois das armas do hoplita. É entrar em terreno especulativo sugerir-se que em outras versões da vingança do herói ele usaria somente uma tática em detrimento da outra ou que a introdução de uma ou outra (geralmente as armas hoplíticas, por serem menos "arcaicas" que o arco) seria uma "invenção" do poeta da nossa Odisseia. Nem mesmo o fato de o nome de seu filho talvez apontar paro o uso do arco, já que Telêmaco pode significar "o que luta de longe", dirime a questão, pois outra etimologia possível é "o que luta longe", com o que se indicaria outro tema ligado a Odisseu, o nóstos de quem esteve lutando

\footnotetext{
${ }^{38}$ Acerca desse tipo de discurso na poesia épica, cf. Martin, op. cit., p. 66-77.

${ }^{39}$ Embora Edwards, op. cit., p. 24 considere a bazófia apropriada, seu quadro sinóptico sobre a tocaia nas páginas 96-97 revela que o motivo da "censura" como momento final de uma emboscada só aparece uma vez na Iliada, justamente na cena em questão; na Odisseia, ele ocorre em 2 das 17 emboscadas representadas (em outras duas, porém, de forma implícita).

${ }^{40}$ Cf. Edwards, op. cit., p. 23-24.

${ }^{41}$ Para outras "anomalias" em relação à jactância de Páris, cf. Muellner, L. C. The meaning of Homeric "eukhomai" through its formulas. Innsbruck: Institut für Sprachwissenschaft, 1976, p. 89-91; para uma visão menos negativa de Páris, cf. Taplin, O. Homeric soundings. The shaping of the "Iliad". Oxford: University Press, 1992, p. 164.

${ }^{42}$ Para uma avaliação positiva desse eco, cf. Andersen, $\varnothing$. The Diomedesgestalt in der "Ilias". Oslo: Universitetsvorlaget, 1978, p. 138.
} 
em Troia e demorou dez anos para retornar para sua casa. ${ }^{43}$ Assim, a imagem guerreira de Odisseu composta por Atena no início do poema, ao mesmo tempo, faz referência ao modo como se dará a vingança contra os pretendentes de Penélope ${ }^{44}$ e evoca materiais tradicionais conhecidos pela audiência do poema. ${ }^{45}$

\section{O veneno}

Resta discutir o veneno. Em primeiro lugar, nada indica que as flechas utilizadas por Odisseu na sua vingança contra os pretendentes tivessem sido untadas com veneno. Assim, comecemos pelo epíteto que qualifica o veneno (phármakon), "homicida" (androphónos), que, na poesia hexamétrica arcaica, só não é usado para pessoas (ou deuses: sobretudo Heitor e Ares) na nossa passagem e no (pseudo-) hesiódico Escudo, v. 420, para qualificar a lança de Héracles. ${ }^{46}$ Além disso, um veneno a ser usado por um herói para matar seus inimigos não tem paralelo nos poemas homéricos.

\footnotetext{
${ }^{43}$ Acerca dos nomes dos filhos que apontam para o heroísmo do pai, e as possibilidade para a etimologia de "Telêmaco", cf. von Kamptz, H. von. Homerische Personennamen. Sprachwissenschaftliche und historische Klassifikation. Göttingen: Vandenhoeck \& Ruprecht, 1982, p. 31-33; Nagy, op. cit., p. 146; e Peradotto, J. Man in the middle voice. Name and narrative in the "Odyssey". Princeton: University Press, 1990, p. 106-107.

${ }^{44}$ Nesse caso, a imagem funcionaria ao modo de um duplo da vingança; acerca dessa estrutura típica da poesia oral hexamétrica, cf. Fenik, B. Studies in the "Odyssey". Hermes Einzelschriften. Wiesbaden: Franz Steiner, v. XXX, 1974, p. 133-232, e Kelly, A. How to end an orally-derived epic poem? Transactions of the American Philological Association. Baltimore, n. CXXXVII, p. 371-402, 2007. Outro momento em que o modo da vingança aparece em uma escala menor é durante a disputa com os jovens feácios. ${ }^{45}$ Discordo, portanto, de Dirlmeier, op. cit., p. 9-10, para quem, mesmo na Odisseia, Odisseu é um hoplita que basicamente não usa o arco; sua interpretação (p. 11-12) de Od. VIII, 214-33, porém, é arbitrária, já que a função da cena não é apenas indicar o modo como ocorreria a vingança de Odisseu contra os pretendentes.

${ }^{46} \mathrm{Cf}$. Hesiod. The shield; Catalogue of women; Other fragments. Edited and translated by Glenn W. Most. Cambridge, Mass.: Harvard University Press, 2007, p. 34.

${ }^{47}$ Há testemunhos literários de Héracles usando o sangue da Hidra contra Gerião e contra os centauros, mas, nesse caso, trata-se de criaturas maravilhosas que ultrapassam o universo marcadamente humano dos poemas homéricos; cf. West, op. cit., p. 107.
} 
Há uma passagem na Ilíada, porém, que talvez esteja ligada tematicamente ao trecho em questão. Nesse poema o heroísmo de Aquiles e o de seu antagonista Heitor são amiúde apresentados como selvagens, especialmente através de símiles ou do modo como eles se opõem a outros heróis. No canto XXII, quando ambos vão combater, o primeiro é qualificado como pelôrion ("enorme, assombroso": v. 92); para o segundo, é construído um símile:

Como serpente montesa na boca da toca aguarda o varão, depois de pastar drogas malignas; entra nela raiva terrível, e aterrorizante é seu olhar ao voltear em torno da toca assim Heitor, com ímpeto inextinguível, não recuava...

(Il.XXII, 93-96)

Embora o veneno seja representado como algo que a cobra toma de fora para si, ${ }^{49}$ nesse símile sua função principal não é servir de arma, mas indicar a origem da emoção que gera o desejo de defesa da sua toca, ${ }^{50}$ ou melhor, a raiva que sente pelo homem que percebe como querendo atacá-la. Por outro lado, a raiva é homóloga ao ímpeto de Heitor, ou seja, o narrador, ao mencionar o veneno como razão para uma criatura frágil como uma serpente querer enfrentar algo tão maior que ela quanto um homem, expressa o desequilíbrio entre Aquiles e Heitor. ${ }^{51}$

Se, tendo esse desequilíbrio em mente, voltarmos para a história de Odisseu, podemos pensar que a imagem do herói construída por Atena combina a sua força, visível através da armadura hoplítica, e uma certa fragilidade, que pode apontar para sua idade e/ ou para a dificuldade da empreitada para a qual o veneno seria necessário. O veneno, assim, não é um mero detalhe, uma desculpa para Atena/ Mentes esclarecer a Telêmaco por que Odisseu teria aparecido na corte de Anquíalo, pai de

\footnotetext{
${ }^{48}$ Acerca desse adjetivo, que não tem nada de intrinsecamente negativo, mas sugere criaturas sobre-humanas, cf. West, M. L. Indo-European poetry and myth. Oxford: University Press, 2007, p. 425-426.

${ }^{49}$ Cf. Richardson, N. The "Iliad": a Commentary. Cambridge: University Press, 1993. Vol. VI, p. 116.

${ }^{50} \mathrm{Cf}$. Walsh, T. R. Fighting words and feuding words. Anger and the Homeric poems. Lanham: Rowman and Littlefield, 2005, p. 129.

${ }^{51}$ Cf. Bergold, W. Der Zweikampf des Paris und Menelaos. Bonn: Adolf Habelt, 1977, p. 27-9; de Jong, I. J. F. de. Narrators and focalizers. The presentations of the story in the "Iliad". Amsterdam: Grüner, 1987, p. 129-30.
} 
Mentes, e ter permitido ao táfio formar essa memória relevante para a persuasão hic et nunc de Telêmaco.

Embora o texto dê a impressão de que Mentes e Odisseu tenham idades semelhantes - Mentes é rei dos táfios no presente (Od. I, 181), mas, quando viu Odisseu pela primeira vez, reinava seu pai (é o que se depreende de Od. I, 253-64) -, é sobretudo o contexto do discurso de Atena como um todo que sugere que tanto Odisseu como Mentes eram muito jovens quando pela primeira vez se viram, ${ }^{52}$ já que, ao citar a façanha do jovem Orestes (v. 296-302), Atena explicita, para o receptor do poema e para o próprio Telêmaco, que ela está lançando mão do paradigma do "guerreiro jovem" para fazer com que Telêmaco, por fim, decida agir como filho de seu pai.

Mesmo se a juventude de Odisseu não estiver sendo evocada, o veneno aponta, no mínimo, para uma façanha que Odisseu teria dificuldade de executar apenas como um hoplita convencional. Essa interpretação parece ser ecoada pelos pretendentes no canto seguinte:

Certamente Telêmaco cogita nossa matança.

Ou conduzirá alguns protetores da arenosa Pilos

ou até de Esparta, pois agora anseia terrivelmente,

ou pretende também a Éfira, de fértil solo,

ir, para de lá trazer drogas tira-vida (thumophthóra phármaka),

lançá-las numa ânfora e perder-nos a todos. (Od. II, 325-30)

Isso comentam os pretendentes logo após Telêmaco reafirmar sua intenção de viajar em busca de um meio de destruir os desmedidos jovens (v. 310-20), pois não é mais uma criança ingênua (nêpios, v. 313). Já havia ficado implícito no diálogo entre Telêmaco e Atena/ Mentes no canto I e explícito na assembleia dos itacenses no canto seguinte que a disparidade numérica entre Telêmaco (e Odisseu) e os pretendentes é algo que tornaria muito difícil uma medida punitiva unilateral contra eles. Em Od. II, 325-30, porém, não se trata apenas de um duplo da história do veneno no canto anterior, mas de uma precisão ainda maior de como vai ocorrer a vingança de Odisseu, a saber, durante um banquete.

Nesse sentido, vale a pena comparar a história contada por Atena e o seu duplo refletido na fala anônima dos pretendentes com uma façanha pretérita de Odisseu narrada por Menelau a Telêmaco:

${ }^{52}$ van Thiel, op. cit., p. 42, e de Jong, op. cit. (n. 3), p. 32, assumem, sem discussão, que Odisseu era jovem. 
Incrível, realmente no leito de varão juízo-forte cobiçaram [sc. pretendentes] deitar-se, eles próprios sendo covardes. Como quando a cerva, na moita de forte leão, os filhotes adormece, recém-nascidos lactentes, e investiga encostas e vales herbosos, pastando, e ele então se achega de seu leito e sobre aqueles dois ultrajante fado lança assim Odisseu sobre eles ultrajante fado lançará. Tomara, ó Zeus pai, Atena e Apolo, com o porte que, então, em Lesbos bem-construída, na disputa com Filomeleides, se ergueu, lutou e o derrubou com força, e se alegraram todos os aqueus, assim aos pretendentes encontrasse Odisseu: todos seriam destino-veloz e bodas-amargas. (Od. IV, 333-46)

Esse trecho é o caprichado proêmio da narração do retorno de Menelau e funciona, ao mesmo tempo, como uma fala de bom augúrio para Telêmaco e uma sugestão, para o receptor do poema, de como poderá ocorrer a vingança de Odisseu. ${ }^{53}$ Dessa vez, não há nenhum menção à astúcia de Odisseu, mas apenas à sua força bruta, tanto no símile quanto na historieta, e em ambos se acentua a estupidez ou ingenuidade por parte dos adversários do algoz. Agora a fragilidade não está do lado de Odisseu, mas dos pretendentes. ${ }^{54} \mathrm{~A}$ vingança configurada nessa fala é "aquileica", ou seja, sem a astúcia empregada

\footnotetext{
${ }^{53}$ Além disso, é provável (cf. Louden, op. cit., p. 17) que, através da figura de Filomeleides, se aluda ao tema da má hospitalidade na sua variação "hospedeiro desafia hóspede em uma prova mortal", com o que, de novo, se aponta para a derradeira vingança de Odisseu contra os pretendentes.

${ }^{54} \mathrm{O}$ destaque conferido à fragilidade, inclusive por razões etárias, é uma das razões para o traço não naturalista do símile; para uma apreciação mais simpática do símile que a de Schnapp-Gourbeillon, François. Lions, héros, masques. Les répresentations de l'animal chez Homère. Paris: Maspero, 1981, p. 60, cf. Steiner, D. Homer: "Odyssey", Books XVII and XVIII. Cambridge: University Press, 2010, p. 92-93. A fragilidade das vítimas do leão é uma razão para não se considerar a história resumida na sequência um duplo do símile (ou vice-versa), como quis a Análise (cf. van Thiel, op. cit., p. 71). Além disso, o símile parece-me ser um dos momentos, talvez nem tão raros, onde Homero mostra-se bem-humorado ou espirituoso; esse humor homérico foi-me assinalado por Liz Irwin, que destacou o episódio de Circe e o de Odisseu diante de Nausícaa, ao ser assemelhado, pelo narrador, a um leão.
} 
por Odisseu e metonimicamente sugerida pelo veneno mencionado nos cantos I e II. ${ }^{55}$

Por fim, o último elemento da viagem de Odisseu em busca do veneno que pode ser explorado é a sua bipartição. Não chegamos muito longe atentando para o nome das localidades, ${ }^{56}$ embora seja possível que elas aludam a outras histórias ligadas a Odisseu ou até mesmo aos argonautas. ${ }^{57} \mathrm{O}$ que precisamos explicar, porém, é por que Atena/ Mentes menciona que Ilo teria negado o pedido de Odisseu.

Em primeiro lugar, o que Mentes diz é que Ilo teve medo da némesis ("indignação") divina, não que essa necessariamente viria. Que o seu pai tenha dado o veneno a Odisseu e nada aparentemente lhe aconteça, isso indica que a ação não precisaria necessariamente ser punida, direta ou indiretamente, pelos deuses. Os feácios, que, por serem da estirpe de Poseidon, excelem na arte náutica, ${ }^{58} \mathrm{em}$ nenhum momento titubearam no transporte do seu hóspede, muito embora a história que Odisseu lhes contou - o cegamento de Polifemo e a sua prece ao pai Poseidon -, aliada à previsão de que um dia algo terrível aconteceria devido a uma irritação do deus (Od. VIII, 564-71) poderia tê-los tornado mais cuidadosos ao modo de Ilo ou de Eólo (Od. X, 72-75). Assim, no caso da história de Atena, não parece ser (a utilização d)o veneno em si um crime passível de punição pelos deuses, mas a transmissão de um conhecimento ou um favorecimento - em suma, uma dádiva ou honra - de origem divina do qual o rei foi o beneficiário, já que não é fácil para um mortal definir os limites do uso daquilo que ele recebeu de um deus. ${ }^{59}$

\footnotetext{
${ }^{55}$ Essa oposição temática - para a qual, de acordo com van Thiel, op. cit., p. 42, se dá a menção do veneno - é condensada em diversas fórmulas na Ilíada e na Odisseia; cf., por ex., "com truque ou às claras" (Od. I, 295), referente ao modo como Telêmaco, segundo Atena/ Mentes, poderia vingar-se dos pretendentes.

${ }^{56}$ Cf. West, op. cit. (n. 3), p. 108; elas talvez aludam a rotas comerciais que passavam por Ítaca no séc. VIII (cf. Malkin, I. The returns of Odysseus. Colonization and ethnicity. Berkeley: University of California Press, 1998, p. 72).

${ }^{57}$ Cf. Malkin, op. cit., p. 128-29.

${ }^{58}$ Od. VI, 266-73 e XIII, 128-30.

${ }^{59}$ Vale notar que a gama de usos de némesis é bastante ampla, às vezes significando pouco mais que raiva (cf. Cairns, D. L. Aidôs: the psychology and ethics of honour and shame in ancient Greek literature. Oxford: University Press, 1993, p. 53); diz esse mesmo autor (p. 85, n. 123) sobre o uso do verbo cognato em Od. I, 263 que seu sentido é “"ele temeu a cólera dos deuses', e, portanto, como um medo prospectivo de desaprovação, overbo aproximase de aideîsthai nesse contexto; aideîsthai theoús, entretanto, somente é achado em contextos de súplica e amizade ligada à hospitalidade em Homero".
} 
Mais significativo que a negativa em si, porém, é a oposição, sugerida pelo comportamento dos dois reis, entre (o medo da) némesis (dos deuses) e philía (“amizade"), pois já no diálogo entre Atena e Zeus que abre o poema (Od. I, 44-95) Odisseu é apresentado como um herói que, potencialmente, pode gerar ódio ou simpatia entre os deuses. $\mathrm{Na}$ economia do canto I e, na verdade, de toda a Telemaquia, especialmente nos cantos I-III, Telêmaco é auxiliado de perto por Atena, o que justamente mostra como sua linhagem é - tem sido - amada pelos deuses. ${ }^{60}$ Mesmo que o início do retorno de Odisseu de Troia tenha sido tumultuado indireta ou até mesmo impossibilitado diretamente pela "cólera de Atena", ${ }^{11}$ durante toda a Odisseia não há nenhuma dúvida de que Zeus e Atena estão do lado de Odisseu. Assim, o veneno fornecido pelo pai de Atena/ Mentes assinala ao receptor que a vingança de Odisseu não só será bem sucedida, ${ }^{62}$ mas que Zeus a garantirá.

\section{Conclusão}

Espero ter demonstrado que, de acordo com a lógica da narrativa e os temas empregados na construção do pequeno episódio contado por Atena para Telêmaco, não estamos diante de uma imagem compósita de Odisseu, que deixaria entrever um estrato arcaico, pré-homérico, pré-épico ou até mesmo pré-heroico utilizado para realçar a natureza ambígua do herói ou da sua ação, mas de uma composição, habilmente embutida em um discurso maior.

Os elementos da história de forma alguma vão contra um suposto estatuto épico-heroico, mas assinalam temáticas que são comuns e de forma alguma marginais tanto na Ilíada quanto na Odisseia. Além disso, a história configura uma imagem que, ao mesmo tempo, motiva as ações de Telêmaco e as coloca em perspectiva para o receptor. Por fim, em filigrana, ela indica para o receptor de que modo se dará a vingança de Odisseu contra os pretendentes de sua mulher.

${ }^{60}$ Od. III, 375-79.

${ }^{61}$ Cf. Clay, J. S. The wrath of Athena. Gods and men in the "Odyssey". Lanham: Rowman \& Littlefield, 1997, e, contra, Danek, op. cit., p. 80-89.

${ }^{62}$ Cf. de Jong, op. cit. (n. 3), p. 32. 


\section{Referências}

ANDERSEN, Ø. The Diomedesgestalt in der “Ilias”. Oslo: Universitetsvorlaget, 1978. BAKKER, E. Polyphemos. Colby Quarterly. Waterville, n. XXXVIII, p. 135-50, 2002. BERGOLD, W. Der Zweikampf des Paris und Menelaos. Bonn: Adolf Habelt, 1977. BOLLACK, J. Ulysse chez les philologues. In. La Grèce de personne. Paris: Seuil, 1997, p. 29-59.

CAIRNS, D. L. (1993) Aidôs: the psychology and ethics of honour and shame in ancient Greek literature. Oxford: University Press.

CLAY, J. S. The wrath of Athena. Gods and men in the "Odyssey". Lanham: Rowman \& Littlefield, 1997.

. Odyssean animadversions. In: MONTANARI, F. (Org.). Omero tremila anni dopo. Roma: Edizioni di Storia e Letteratura, 2002, p. 73-83.

DANEK, G. Studien zur Dolonie. Wien: Österreichischen Akademie der Wissenschaften, 1988.

. Epos und Zitat. Studien zu den Quellen der Odyssee. Wien: Österreichischen Akademie der Wissenschaften, 1998.

DIMOCK, G. E. The unity of the "Odyssey”. Amherst: University of Massachusetts Press, 1989.

DIRLMEIER, F. Die Giftpfeile des Odysseus. Heidelberg: Carl Winter, 1966.

DUÉ, C.; EBBOTT, M. "Iliad" 10 and the poetics of ambush. A multitext edition with essays and Commentary. Hellenic Studies. Washington D.C.: Center for Hellenic Studies, vol. XXXIX, 2010.

EDWARDS, A. T. Achilles in the "Odyssey”. Königstein: Hain, 1985.

FENIK, B. Studies in the "Odyssey”. Hermes Einzelschriften. Wiesbaden: Franz Steiner, vol.XXX, 1974.

FORD, A. Homer: the poetry of the past. Ithaca: Cornell University Press, 1992.

HAFT, A. J. "The city-sacker Odysseus" in "Iliad" 2 and 10. Transactions of the American Philological Association. Baltimore, n. CXX, p. 37-56, 1990.

HAINSWORTH, J. B. The "Iliad": a Commentary. Cambridge: University Press, 1993. Vol. III.

HALLIWELL, S. Greek laughter. A study of cultural psychology from Homer to early Christianity. Cambridge: University Press, 2008.

HESIOD. The shield; Catalogue of women; Other fragments. Edited and translated by Glenn W. Most. Cambridge, Mass.: Harvard University Press, 2007.

HÖLSCHER, U. Die Odyssee. Epos zwischen Märchen und Roman. München: C. H. Beck, 1988.

HOMERI Odyssea. Recognovit Helmut van Thiel. Hildesheim: Olms, 1991.

HOMERI Ilias. Iterum recognovit Helmut van Thiel. Hildesheim: Olms, 2010. 
HUNT, P. Military forces. In: SABIN, P.; van WEES, H.; WHITBY, M. (orgs.) The Cambridge history of Greek and Roman warfare. Cambridge: University Press, 2008, p. 108-146. Vol. I.

JONG, I. J. F. de. Narrators and focalizers. The presentations of the story in the "Iliad". Amsterdam: Grüner, 1987. 2001. .A narratological Commentary on the "Odyssey". Cambridge: University Press,

von KAMPTZ, H. Homerische Personennamen. Sprachwissenschaftliche und historische Klassifikation. Göttingen: Vandenhoeck \& Ruprecht, 1982.

KELLY, A. How to end an orally-derived epic poem? Transactions of the American Philological Association. Baltimore, n. CXXXVII, p. 371-402, 2007.

LATACZ, J. et al. Homer "Ilias": Gesamtkommentar. Band II: Zweiter Gesang. Faszikel 2: Kommentar. München: Saur, 2003.

LORD, A. B. The singer of tales. Cambridge, Mass.: Harvard University Press, 1960.

LOUDEN, B. The "Odyssey". Structure, narration and meaning. Baltimore: Johns Hopkins University Press, 1999.

MACKIE, H. Talking Trojan. Speech and community in the "Iliad". Lanham: Rowman \& Littlefield, 1996.

MALKIN, I. The returns of Odysseus. Colonization and ethnicity. Berkeley: University of California Press, 1998.

MARTIN, R. P. The language of heroes. Speech and performance in the "Iliad". Ithaca: Cornell University Press, 1989.

MERKELBACH, R. Untersuchungen zur Odyssee. 2. ed. München: Beck, 1969.

MUELLNER, L. C. The meaning of Homeric enkhomai through its formulas. Innsbruck: Institut für Sprachwissenschaft, 1976.

NAGY, G. The best of the Achaeans. Concepts of the hero in archaic Greek poetry. Baltimore: Johns Hopkins University Press, 1979.

Pindar's Homer. The lyric possession of an epic past. London: Johns Hopkins

University Press, 1990.

PAPADOPOULOU, T. Heracles and Euripidean tragedy. Cambridge: University Press, 2005.

PERADOTTO, J. Man in the middle voice. Name and narrative in the "Odyssey". Princeton: University Press, 1990.

REECE, S. The strangers welcome. Oral theory and the aesthetics of Homeric hospitality scene. Ann Arbor: University of Michigan Press, 1993.

RICHARDSON, N. The "Iliad": a Commentary. Cambridge: University Press, 1993. Vol. VI.

. Three Homeric hymns: to Apollo, Hermes, and Aphrodite. Cambridge: University Press, 2010. 
RIJKSBARON, A. Discourse cohesion in the proem of Hesiod's "Theogony". In: BAKKER, S.; WAKKER, G. (Org.). Discourse cohesion in ancient Greek. Amsterdam Studies in Classical Philosophy. Leiden: Brill, 2009. Vol. XVI.

ROUSSEAU, P. Lintrigue de Zeus. Europe. Paris, n. QCCCLXV, p. 120-158, 2001. RÜTER, K. Odysseeinterpretationen. Untersuchungen zum ersten Buch und zur Phaiakis. Editado por K. Matthiessen. Göttingen: Vandenhoeck \& Ruprecht, 1969.

SCHNAPP-GOURBEILLON, F. Lions, héros, masques. Les répresentations de l'animal chez Homère. Paris: Maspero, 1981.

SNELL, B. (Begründer). Lexikon des frühgriechischen Epos. 4 vol. Göttingen: Vandenhoeck \& Ruprecht, 1955-2010.

STEINER, D. Homer: “Odyssey”, books XVII and XVIII. Cambridge: University Press, 2010.

STOEVESANDT, M. Homer "Ilias": Gesamtkommentar. BandIV: Sechster Gesang. Faszikel 2: Kommentar. Berlin: Walter de Gruyter, 2008.

TAPLIN, O. Homeric soundings. The shaping of the "Iliad". Oxford: University Press, 1992.

van THIEL, H. Odysseen. Basel: Schwabe, 1988.

WALSH, T. R. Fighting words and feuding words. Anger and the Homeric poems. Lanham: Rowman and Littlefield, 2005.

van WEES, H. Homeric warfare. In: Morris, I.; Powell, B. (Org.). A new Companion to Homer. Leiden: Brill, 1997.

WEST, M. L. Indo-European poetry and myth. Oxford: University Press, 2007.

WEST, S. Books i-iv. In: Hainsworth, J. B.; Heubeck, A.;

(Org.). A Commentary

on Homer's "Odyssey". Oxford: University Press, 1988. V. I, p. 49-245. 